\title{
Düzey Derslikleri Uygulamasına Yönelik Veli Görüşleri
}

\section{Ümran ŞAHIN*}

Öz: Bu araştırmanın amacı; düzey derslikleri uygulaması hakkında velilerin bilgilerini ve bu uygulamanın çocuklarına akademik, sosyal ve psikolojik açısından etkileri hakkındaki düşüncelerini ortaya koymaktır. $\mathrm{Bu}$ araştırmada fenomenoloji deseninden yararlanılmıştır. Veriler, velilerle yapılan görüşmeler yoluyla toplanmış ve içerik analiz tekniği kullanılmıştır. Araştırmaya katılan veliler açısından düzey derslikleri uygulamasına ilişkin görüşler; "Düzey Dersliklerinin Anlamı”, "Düzey Dersliği Oluşturma Ölçütleri”, “Düzey Derslikleri Uygulamasının Olumlu ve Olumsuz Yönleri” ve “Uygulamaya İlişkin Velilerin Düşünceleri” adıyla dört ana temadan oluşmaktadır. Düzey derslikleri, veliler tarafından akademik olarak yakın başarı gösteren öğrencileri gruplandırma olarak tanımlanmaktadır. Düzey dersliği oluşturma ölçütleri temasında ise veliler öğrencilerin akademik başarılarının yanında öğrenci hal ve tutumlarının, öğretmen kanaatlerinin, sanatsal ve sportif faaliyetlerdeki başarıların da dikkate alınması gerektiğini vurgulamışlardır. Düzey derslikleri uygulamasının olumlu ve olumsuz yönleri temasında ise veliler uygulamanın çocuklarının kendi bilişsel hızlarında öğrenmeleri açısından etkin olduğunu ancak arkadaşlık ilişkileri ve çocuklarda kaygı, stres oluşturması açısından olumsuzluklarını vurgulamışlardır. Uygulamanın ilişkin velilerin düşünceleri teması pozitif ve negatif düşünce alt temalarında ele alınmıştır.

Anahtar kelimeler: Düzey derslikleri, Veli görüşleri, Fenomenoloji

\section{The Implementation of Ability Grouping According to Parent Views}

Abstract: The aim of this study is to reveal the opinions of the parents about the effects of ability grouping on their children academically, socially and psychologically by enabling them to evaluate the implementation of ability grouping. In this study, phenomenological design is used. The data was gathered through interviews conducted with the parents, and content analysis technique was used. The opinions of the parents about the implementation of ability grouping were divided into four main themes including "The Definition of Ability Grouping", "The Criteria to Design Ability Grouping", "The Positive and Negative Aspects of the Application of Ability Group" and " The thoughts of parents about the Implementation". Ability grouping is defined by the parents as grouping the students who have similar academic

*Dr.Öğrt.Üyesi, Pamukkale Üniversitesi, Eğitim Fakültesi, Temel Eğitim Bölümü, Email: usahin@pau.edu.tr Orcid No: 0000-0001-5214-0417

\begin{tabular}{lll}
\hline Gönderim:11.10.2018 $\quad$ Kabul:06.01.2019 & Yayın:15.03.2019
\end{tabular}


success levels. As for the criteria to design ability grouping, the parents emphasized that along with students' academic success, students' behaviours and attitudes, teacher opinions about students, students' success in art and sports activities need to be taken into account. When it comes to the theme of the positive and negative aspects of the application of ability grouping, the parents stated that the implementation is effective as it enables their children to learn according to their own cognitive pace; however, it creates some disadvantages for children in terms of peer relationships and leads to stress and anxiety. The theme of parent thougts about the implementation was dealt in two subthemes as positive and negative thoughts.

KeyWords: Ability Grouping, Parent Views, Phenomenology

\section{Giriş}

Türkiye’de dört y1llık ilkokul eğitimini tamamlayan öğrenciler zorunlu eğitim kapsamında ortaokul eğitimine geçiş yaparlar. Ortaokullar dört y1l süreli olmakla birlikte lise eğitimi için hazırlık niteliğindedir. MEB'in 1739 sayılı temel kanununda da belirtildiği gibi ortaokullar, öğrencilerin yetenek ve gelişimleri dikkate alınarak lise eğitimini destekleyecek nitelikte olmalıdır. Ayrıca kanunda milli eğitimin yöneltme işlevinin ilköğretimde başladığına dair ibare bulunmaktadır. Bu durumda ortaokulların amaçlarından biri öğrencileri ilgi ve yetenekleri doğrultusunda bir üst öğrenime hazırlamaktır.

Ortaokul eğitimini tamamlayan öğrenci MEB tarafindan düzenlenen merkezi sınavlara girmektedirler. Öğrenciler aldıkları başarı puanlarına göre liselere giriş yapmaktadırlar. Bazı ortaokullar, öğrencilerinin başarılı liselere geçiş yapabilmeleri için düzey derslikleri uygulaması gibi farklı uygulamalar yapabilmektedirler.

Düzey derslikleri kavramının alanyazında farklı tanımlamaları bulunmaktadır. Yabancı alanyazında “ability group, ability grouping, tracking, curriculum tracking” olarak kullanılan kavramlar, Türkiye'de seviye grubu, düzey kümesi, düzey derslikleri olarak kullanılmaktadır (Karademir, 2007). Düzey dersliklerini, Cheung ve Rudowicz (2003); okullar ve öğretmenler tarafından öğrencileri belli becerilerine göre sınıflara ayırma uygulamasıdır; Slavin (1993); öğrencilerin akademik başarı, zeka, öğretmen kanaatlerinden birini ya da birkaç tanesini dikkate alarak, kendi seviyelerine uygun dersliklerde öğrenim görmelerini esas alan bir düzey kümesi uygulamasıdır şeklinde tanımlamışlardır. Bu tanımlar kapsamında düzey derslikleri için, okulların öğrencileri sosyal becerileri ve genellikle bilişsel kabiliyetleri doğrultusunda benzer nitelikte olan öğrencilerin aynı derslikte öğrenim görmeleridir denilebilir. Düzey 
dersliklerini belirlemede genellikle bilişsel kabiliyet önemli olmakla birlikte Slavin (1993)'in belirttiği gibi öğrencilerin akademik başarıları, kabiliyetleri, hazır bulunuşlukları veya öğretmen kanaatleri gibi ölçütler dikkate alınabilir.

Okullarda öğrencilerin sosyal ya da bilişsel kabiliyetlerine göre sınıflandırılmasındaki amaç bireysel öğrenme hızlarına göre eğitim yapma isteğinden kaynaklanıyor olabilir. Ançak Halis(2002)'in de belirttiği gibi yeteneğin ölçülmesi bir zorluktur. Bu zorluk, yeteneğin hangi kriterlere göre kimler tarafından belirleneceğinde netlik oluşturulamaması durumunda isabetsiz sınıflandırma riski söz konusudur. Ortaokullar bu riski göze almakla birlikte yüksek başarı elde edebilmek için sadece bilişsel kabiliyetleri baz almaktadırlar. Cady (2011), Karademir(2007), Yılmaz ve arkadaşları (2009) da yaptıkları çalışmalarda öğrencilerin düzey belirlenmesinde sadece bilişsel yeteneklerine bakıldığına değinmişlerdir. Yılmaz ve arkadaşları (2009) yaptıkları çalışmada bu uygulamaların öğrencilerin sınavlardan aldıkları puana veya akademik ortalamalarına göre gruplara ayırarak seviyelerine uygun dersliklerde eğitim görmeleri sağlandığını ve genelde "A" sınıflarında akademik olarak başarılı öğrenciler, B, C, ve D sınıflarında ise azalan bir başarı sırasına göre diğer öğrenciler yer aldıklarını vurgulamışlardır.

Türkiye’de MEB 1968 ve 1995 programlarında düzey derslikleri uygulamasını yürürlüğe koymuştur (MEB, 1995). Ancak ileriki yıllarda bu uygulama kaldırılmıştır. Hatta MEB'in 2009-2011 İlköğretim Genel Müdürlüğü’nün genelgelerinde düzey derslikleri oluşturulmasının çocuk haklarına, insan haklarına ve Anayasaya aykırı olduğu ve öğretim programında çocuğa kazandırılması hedeflenen davranışların oluşmasına engel olabileceği gerekçesiyle okullarda düzey derslikleri veya öğrencilerin başarılarına göre ayrı sınıflar oluşturulmaması gerektiği belirtilmektedir (İlköğretim Genel Müdürlüğü, 2009; 2011). Ancak günümüzde bu genelgeye rağmen okullarda düzey derslikleri uygulaması yapılmaktadır.

Avrupa'da ise düzey derslikleri uygulamasının farklı şekillerde yapıldı̆̆ı alanyazında yer almaktadır. Örneğin; ABD’de 1916 yılından itibaren farklı düzey derslikleri uygulamaları olduğu görülmektedir (Kulik and Kulik, 1992). Türkiye'de ve yurtdışında yapılan çalışmalar düzey dersliklerinin öğrenci başarısını artırmak, sınıf disiplinini sağlamak, öğretim yöntemlerinde bütünlüğü sağlamak amacıyla uygulandığını ancak istenilen başarının elde edilemediğini göstermektedir (Ansalone ve Biafora, 2004; Heck vd., 2004; Kutnick vd., 2005; Toomela vd., 2006). Ancak Türkiye'de hala kullanılmaktadır. Ayrıca Türkiye’de ve yurtdışında yapılan çalışmalar düzey derslikleri uygulamasının genelde öğretmen, idareci ve öğrenci görüşleri doğrultusunda değerlendirildiği (Gömleksiz (1997); Karademir (2007); 
Toomela vd. (2006); Yılmaz vd. (2009); Zimmer (2003); Halis (2002) veli görüşlerine ise başvurulmadığı görülmüştür.

Buradan hareketle bu çalışmanın amacı düzey derslikleri uygulamasına velilerin gözüyle bakmaktır. Velilere göre düzey derslikleri uygulamasının amacına ulaşıp ulaşmadığını belirleyebilme açısından çalışma önemli görülmektedir. Ayrıca bu çalışmada; düzey derslikleri uygulamasını velilerin değerlendirmesine olanak tanıyarak uygulamanın çocuklarına akademik, sosyal ve psikolojik açısından etkileri hakkındaki düşünceleri ortaya konulmak istenmiştir.

\section{Yöntem}

$\mathrm{Bu}$ bölümde; araştırmanın modeli, çalışma grubu, veri toplama araçları, verilerin toplanması ve analizi hakkında bilgi verilmiştir.

\section{Araştırma Modeli}

Ortaokul düzeyinde, düzey derslikleri uygulaması yapılan okullarda (ortaokullarda görev yapan öğretmenlerden bilgi alarak okullar belirlenmiştir) çocuğu olan velilerin düzey derslikleri ile ilgili görüşlerini açıklamaya çalışan bu araştırmada nitel araştırma desenlerinden fenomenoloji deseninden yararlanılmıştır. Kaynağını felsefe ve psikolojiden alan fenomenolojide, farkında olduğumuz ancak ayrıntılı bir fikre sahip olmadığımız olguların, kişilerin veya bir grubun edindiği tecrübeleri açısından açıklanması durumudur (Christensen, Johnson and Turner, 2015; Yıldırım ve Şimşek, 2013; Merriam, 2013, Creswell, 2013). Fenomenoloji; araştırmacıya, yaşanmış deneyimleri nasıl anlaşılır hale gelebileceğine ve inceleyebileceğine ilişkin zengin fikirler verir (Smith, Flowers, \& Larkin, 2009). Bu araştırmada da velilerin kişisel deneyimlerini nasıl anlamlandırdıkları incelemek amaçlandığından fenomenoloji deseninden yararlanılmıştır.

\section{Çalışma Grubu}

$\mathrm{Bu}$ araştırmada maksimum çeşitlilik örnekleme yoluna gidilmiştir. Maksimum çeşitlilikte amaç, farklılık gösteren olgular arasında ortak ya da paylaşılan durumların olup olmadığını bulmak ve buna göre sorunun farklı boyutlarını ortaya koymaktır (Yıldırım ve Şimşek, 2013). Bu yolla belirlenen katılımcıların seçiminde cinsiyet, meslek ve çocuklarının okulun farklı sınıf ve düzeylerinde okuyan velilerin olması dikkate alınmıştır. Katılımcılar hakkındaki bilgiler Tablo 1'de verilmiştir (Tablodaki isimler gerçek değildir). 
Tablo 1: Katılımcıların Özellikleri

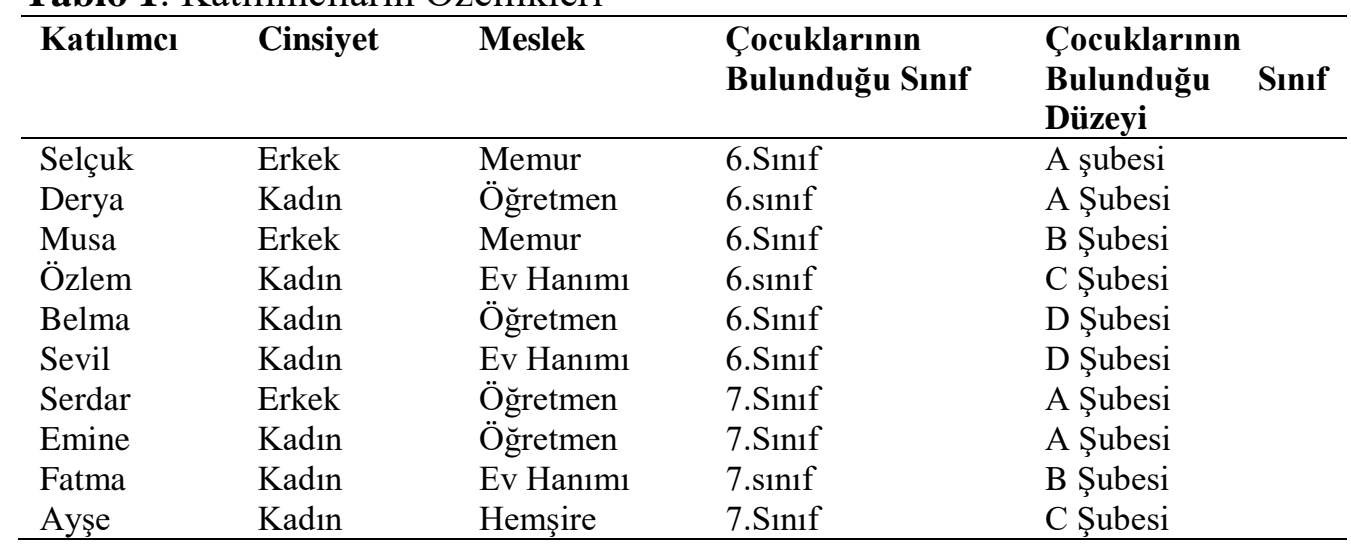

Araştırma kapsamında 3 erkek, 7 kadın olmak üzere 10 veli görüşüne yer verilmiştir. Fenomenoloji araştırmalarında katılımcı sayısı ile ilgili literatürde farklı ifadeler olmakla birlikte Yıldırım ve Şimşek’e (2013) göre çalışmalar 5-6 kişi ile olabilir. Bu araştırmada görüşmeler doyum sağlandığında, veriler tekrara düştüğünde sonlandırılmıştır.

Çalışma düzey dersliği uygulaması yapan Denizli ilindeki bir ortaokuldaki 6. ve 7. sınıf velileri ile yapılmıştır. 5.sınıfların uygulamaya yeni başlamaları ve 8.sınıfların da sınav hazırlığı içinde olmaları çalışmayı olumsuz yönde etkileyebileceği düşüncesiyle 5. Ve 8.sınıf velileri çalışmaya dâhil edilmemiştir. Görüşme yapılan velilerin 2'si devlet memuru, 4'ü öğretmen (1fen bilgisi öğretmeni, 1 sınıf öğretmeni, 1 sosyal bilgiler öğretmeni, 1müzik öğretmeni), 1'i hemşire, 3’ü de ev hanımıdır. Okulda 6.sınıflar 4 şube, 7.sınıflar ise 3 şubedir. Her şubeden en az 1 veli olmasına dikkat edilmiştir.

\section{Veri Toplama Aracı}

Fenomenoloji araştırmalarında veri toplama araçlarından biri görüşmedir. Olgulara ilişkin yaşantıları ve anlamları ortaya çıkarmak için görüşmenin araştırmacılara sunduğu etkileşim, esneklik ve sondalar yoluyla irdeleme özelliklerinin kullanılması gerekmektedir (Yıldırım ve Şimşek, 2013, s. 80). Bu araştırmanın verileri düzey derslikleri uygulaması olan 
okuldaki velilerle yapılan görüşmeler yoluyla toplanmıştır. Velilerin düzey dersliklerine yönelik deneyimlerinden yola çıkarak bu uygulamaya ilişkin görüşlerini belirlemek amacıyla ilgili literatürden ve uzman görüşlerinden (bir temel eğitim, bir ölçme değerlendirme ve bir de eğitim programı alanında uzman) yararlanılarak ana sorular, alternatif sorular ve sondalardan oluşan yarı yapılandırılmış görüşme formu oluşturulmuştur. Görüşme formunun pilot uygulaması çalışma grubu dışındaki üç veli ile yapılmıştır. Görüşmelerden elde edilen veriler ve alan yazın incelemesinden yararlanılarak temel sorular, alternatif sorular ve sondalar hazırlanmış ve araştırmacı dışındaki nitel araştırmada deneyimli iki uzmanın görüşlerine başvurularak görüşme formunun son şekli verilmiştir. Yarı yapılandırılmış görüşme formu 2 bölümden oluşmaktadır. Birinci bölümde katılımcıların kişisel bilgileri ile ilgili sorular, ikinci bölümde düzey derslikleri uygulaması ile yaşadıkları olumlu ve olumsuz yaşantıları, kendilerinin ve çocuklarının üzerindeki etkilerini belirleyici sorular yöneltilmiştir. Görüşmelerde öncelikle katılımcılara araştırmanın amacı hakkında bilgi verilmiştir. Ayrıca görüşmelerin ses kayıt cihazıyla kaydedileceği söylenerek izin alınmıştır. Görüşmeler, katılımcıların kendilerini rahat hissedecekleri ve de sağlıklı görüşmelerin yapılabileceği ortamlarda (ev hanımlarının evinde, öğretmenlerin okullarında...) gerçekleşmiştir. Veliler ile yapılan görüşmeler ortalama olarak 40-45 dakika sürmüştür. Görüşmelerle toplanan veriler bilgisayar ortamına aktarılmıştır.

\section{Verilerin Analizi}

Fenomenoloji araştırmalarında veri analizi, bireylerin deneyimlerini ve düşüncelerini ortaya çıkarmaya yöneliktir. Bu amaçla yapılan betimsel analize göre, elde edilen veriler, daha önceden belirlenen temalara göre özetlenir ve yorumlanır. "Betimsel analiz dört aşamadan oluşur: 1) Betimsel analiz için bir çerçeve oluşturma, 2) Tematik çerçeveye göre verilerin işlenmesi, 3) Bulguların tanımlanması, 4) Bulguların yorumlanması” (Yıldırım ve Şimşek, 2013, s. 256).

Velilerin düzey derslikleri uygulamasına yönelik görüşlerini ortaya çıkarmak amacıyla yapılan bu araştırmanın verilerinin analizinde betimsel analiz tekniği kullanılmıştır. Görüşmelerle toplanan veriler bilgisayar ortamına aktarılmıştır. Bu görüşmelerin analizi: 1) Bilgisayar ortamına aktarılan görüşmelerin kodlanması, 2) Ortak kodlara göre temaların bulunması, 3) Kodların ve temaların uygunluğuna bakarak düzenlenmesi ve tanımlanması 4) Temaların yorumlanması aşamaları izlenerek yapılmıştır. Önceden bir kod listesi 
oluşturulmamıştır, veriler toplandıktan ve bilgisayar ortamına aktardıktan sonra analizleri yapılmıştır. $\mathrm{Bu}$ aşamaların sonucunda veriler aşağıdaki temaları ortaya çıkarmıştır: Veli açısından düzey derslikleri uygulaması kategorisinde; düzey dersliklerinin anlamı, artısı ve eksisiyle düzey derslikleri, düzey dersliği oluşturma ölçütleri, uygulamanın velilere hissettirdikleridir.

\section{Geçerlik ve Güvenirlik Çalışmaları}

Bu çalışmada geçerlik ve güvenilirliği sağlamak için amaçlı örnekleme (düzey derslik uygulaması yapılan okulda öğrencisi olan veliler) ve uzman incelemesi (görüşme sorularının hazırlanmasında ve verilerin analizi aşamalarında) yapılmıştır. Araştırmacı ve bir eğitim programı uzmanı tarafından kodlama güvenirliği açısından veriler incelenerek ayrı ayrı kodlamalar yapılmıştır. Miles ve Huberman (1994:64)' nın güvenirlik formülünden (Güvenirlik= Görüş Birliği × 100 / Görüş Birliği + Görüş Ayrılığ $)$ yararlanılarak görüş birliği ve görüş ayrılığının, araştırmanın güvenirliğine etkisi hesaplanmıştır. Hesaplamanın sonucunda \%89 oranında görüş birliği olduğu görülmüştür Araştırmada geçerliliğini sağlamak amacıyla inandırıcılık (iç geçerlik) için, katılımcı teyidi sağlamak amacıyla görüşme verileri yazılı hale getirilerek katılımcıların onayına sunulmuştur. Teyit edilebilirlik (dış güvenirlik) için ise araştırmanın görüşme verileri, analiz işleminde yapılan kodlamalar, görüşme esnasında yaşanan durumlarla ilgili notlar ve ses kayıtları saklanarak gerektiğinde teyit incelemesine sunulmaya hazırdır.

\section{Bulgular}

Araştırma verilerinin bulguları aşağıdaki temaları oluşturmuştur: Veli açısından düzey derslikleri kategorisine bağlı dört ana tema vardır. Bunlar; Düzey dersliklerinin anlamı, düzey dersliği oluşturma ölçütleri, derslikleri uygulamasının olumlu ve olumsuz yönleri, uygulamaya ilişskin velilerin düşünceleri. Araştırmada oluşturulan kategori ve temalar Şekil 1'de gösterilmiştir. 


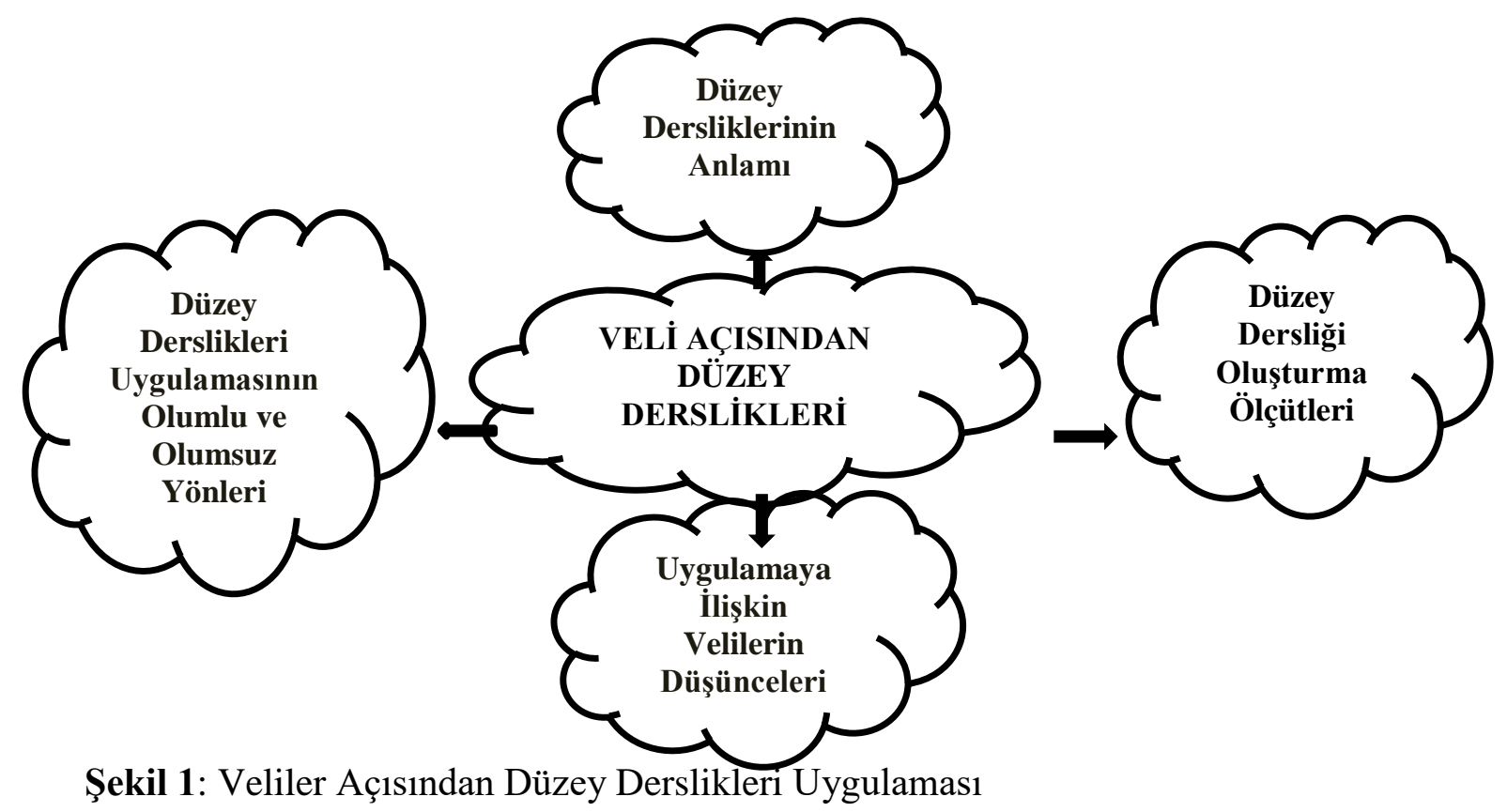

Veliler, Düzey dersliklerinin anlamı temasında düzey derslikleri uygulamasını tanımlamışlardır. Düzey dersliği oluşturma ölçütleri temasında, düzey dersliği uygulamasında hangi ölçütlerin dikkate alındığından ve başka hangi ölçütlerin kullanılabileceğinden bahsetmişlerdir. Düzey derslikleri uygulamasının olumlu ve olumsuz yönleri temasında uygulamanın çocuklarının akademik başarılarına, arkadaşlık ilişkilerine ve psikolojilerine etkilerini açıklamışlardır. Uygulamaya ilişkin velilerin düşünceleri temasında ise çocuklarının üst ya da alt sınıflarda olmasının onları nasıl etkilediğinden bahsetmişlerdir. Bu temalar altında velilerin söylemleri aşağıda ayrıntılı olarak verilmiştir.

\section{Düzey Dersliklerinin Anlamı: Seviye Gruplandırması}

Bu temada veliler çocuklarının içerisinde oldukları sistem hakkında neler bildiklerinden bahsetmişlerdir. Mesleği öğretmen olan veliler bu sistemden haberdarlar hatta görev yaptıkları okulda da aynı uygulamanın olduğunu belirtmişlerdir. Ancak diğer meslek grubundaki veliler ise düzey dersliği uygulamasını ilk defa duyduklarını belirtmişlerdir. Velilerin hepsi düzey dersliği uygulamasını öğrencileri akademik başarılarına göre gruplandırma, aynı seviyede olan öğrencilerin bir arada olması olarak tanımlamışlardır. Bu temaya ait velilerin görüşleri aşağıda yer almaktadir:

Çocukların okulda başarllarına göre gruplandırılması. Çocukların seviyelerinin yakın olanların aynı sınıfa konması (Özlem). 
Özellikle çocukların akademik başarısını ölçen sınıflar şeklinde ayarlanıyor...

Ĕ̆itim ve öğretim diyoruz ama öğretim daha çok baz alınıyor... Yani ĕgitime göre değil öğretime göre gruplandırma (Emine).

Aynı seviyede öğrencilerin bir arada olması. Ama bu seviye sadece sinavlardaki başarılarına göre yani birbirine yakın puanlar alan öğrencilerin aynı sınıfta yer alması diyebilirim (Serdar).

\section{Düzey Dersliği Oluşturma Ölçütleri: Hal ve Tutum, Öğretmen Kanaati, Sportif ve}

\section{Sanatsal Yetenek}

Veliler düzey dersliği oluşturma ölçütlerinde mevcut durumun dişında hal ve tutum, öğretmen kanaati, sanatsal ve sportif faaliyetlerin olması gerektiğini belirtmişlerdir. Düzey dersliği oluşturma ölçütleri teması ve alt temaları şekil 2'de gösterilmiştir.

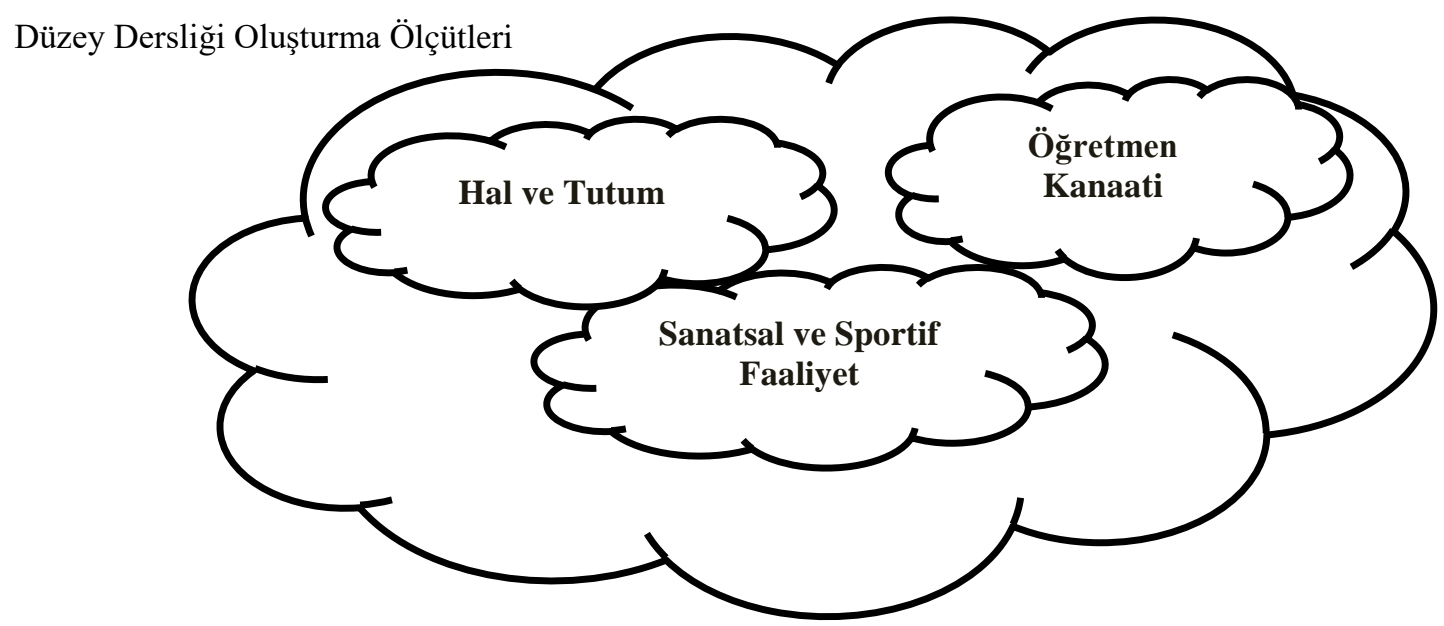

Şekil 2: Düzey Dersliği Oluşturma Ölçütleri Ana Teması ve Alt Temaları

Düzey dersliği oluşturma ölçütleri Şekil 2‘de görüldüğü gibi hal ve tutum, öğretmen kanaati ile sanatsal ve sportif yetenek alt temalarından oluşmaktadır. Veliler, düzey dersliklerinin oluşturulmasında yapılan genel sınav sonuçlarının dikkate alındığını ancak bunun yeterli olmadığını ifade etmişlerdir. Veliler, sınav puanlarının yanında öğrencilerin olumlu hal ve tutumlarının da dikkate alınabileceğini belirtmişlerdir. Örneğin katılımcılardan Ayşe ve Sevil Hanım bu durumu şu şekilde ifade etmiştir:

Çocukların davranışları da dikkate alınabilir. Ders başarısında çok aktif değildir ama davranışlarında örnek olan çocuklar vardır bunlar da dahil edilebilir. Ödevlerini hiç aksatmıyordur. Bunlar da önemli. Dă̆glım yapılabilir (Ayşe). 
Maalesef sadece okulistik sonuçlarına bakıyorlar...bilgisayar yapıyor yani. Ama hal ve davranışlar da dikkate alınmalı bence. Saygı çerçevesi çok önemli. Testte heyecan yapabiliyor tek belirleyici o olmamalı (Sevil).

Bazı veliler ise öğretmenin öğrencinin dersteki tutumuna ve ödevlerini düzenli yapma durumuna göre gözlemlerinin de dikkate alınması gerektiğini vurgulamışlardır:

...Öğretmenin de görüşleri alınmalı bu konuda, ilerleme kaydettiğini düşündükleri çocukları onların düşünceleri ile bir üst sınıfa alınabilir. Tek başına sınav olmamalı (Fatma).

Veliler, öğrencilerin hal ve tutumları, öğretmen kanaatlerinin dikkate alınması yanında öğrencinin varsa sanatsal ve sportif yeteneklerinin de dikkate alınması gerektiğini belirtmişlerdir:

Sinavın yanında çocuğun yaptı̆̆ı etkinlik ve faaliyetlerine de bakılmalı. Çocuk çok iyi bir müzik aleti çallyordur ya da iyi bir basketbolcudur ve bu alanlarda okulu temsil ediyordur. Bu başarılar da dikkate alınmalı, motivasyon açısından (Selçuk).

Düzey dersliklerinin oluşturulmasında veliler, sadece sınav puanlarının dikkate alınmasının yanıltıcı olabileceğini öğrenciyi her yönden değerlendirilmesi gerektiğinin önemi üzerinde durmuşlardır. Öğrencilerin davranışlarının, öğretmen kanaatlerinin, sanatsal ve sportif faaliyetlerinin dikkate alınarak yapılabilecek bir gruplamanın okula ve derslere yönelik motivasyonları için etkili olabileceği görüşündedirler.

Görüşülen velilerden biri ise düzey dersliklerinin oluşturulmasında sadece sınav sonuçlarının yeterli olduğunu belirtmiştir. Buna neden olarak Türkiye'deki okulların amacının akademik başarıyı artırmak olduğundan öğrencilerin seviyelerini belirlemede de tek unsur başarı olması gerektiğini vurgulamıştır. Ayrıca okulların donanımların çocukların özel yeteneklerini belirlemede yetersiz olduklarını belirtmiştir. Fiziksel donanım ve öğretmen yeterlikleri uygun olsa başka ölçütlerin değerlendirilip karma seviye sınıflarının oluşturulmasının daha etkin olacağını vurgulamıştır.

Düzey Derslikleri Uygulamasının Olumlu ve Olumsuz Yönleri: Akademik Başarı, Arkadaşlık İlişkileri, Psikolojik Etkileri

Veliler düzey dersliği uygulamasının artılarının olmasıyla birlikte eksilerinin de olduğunu söylemişlerdir. Bu söylemleri düzey derslikleri uygulamasının olumlu ve olumsuz yönleri temasını oluşturmuştur. Düzey derslikleri uygulamasının olumlu ve olumsuz yönleri teması akademik başarı, arkadaşlık ilişkileri ve psikolojik etkileri alt temalarından oluşmaktadır. 
Düzey Derslikleri Uygulamasının Olumlu ve Olumsuz Yönleri

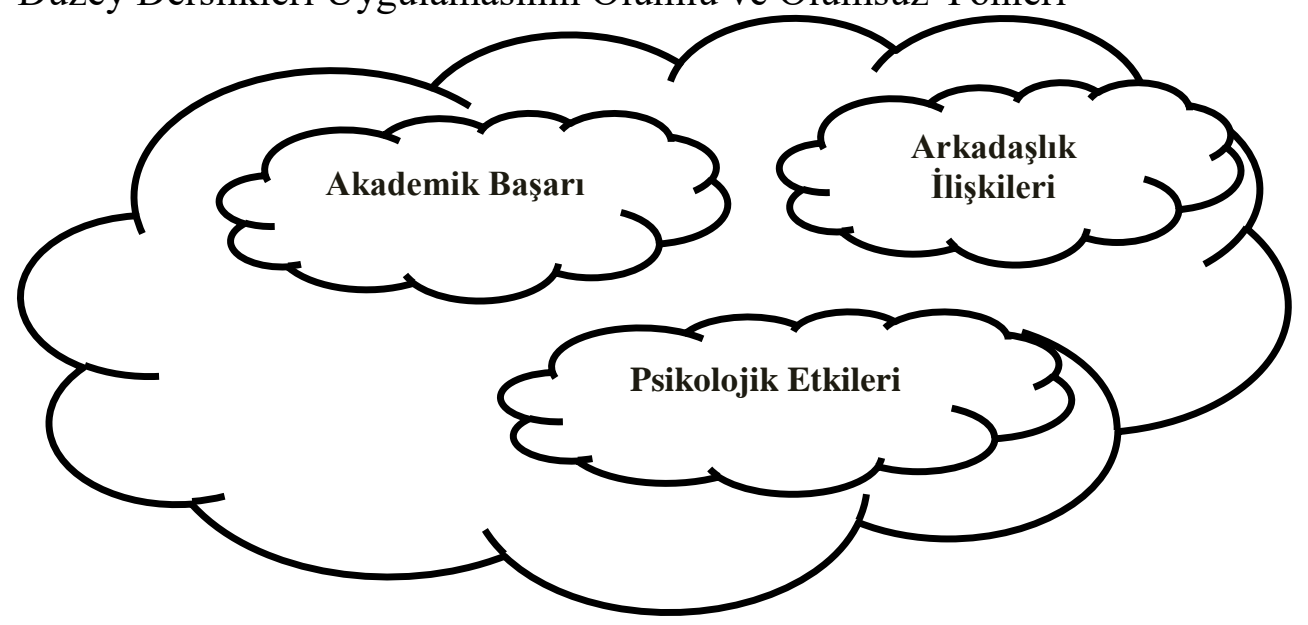

Şekil 3: Düzey Derslikleri Uygulamasının Olumlu ve Olumsuz Yönleri Teması ve Alt temalar Velilerin gözüyle düzey derslikleri uygulaması, akademik başarı açısından olumlu sonuçlar elde edebilir. Özellikle çocukları üst sınıfta olan veliler açısından düzey derslikleri uygulaması akademik başarı açısından bir artı olarak görülmektedir. Çabuk öğrenen çocukların bir arada olması nedeniyle hızlı ilerleme kaydettiklerini belirtmişlerdir. Çocukları alt düzeyde olan veliler ise düzey derslikleri uygulamasının kendi hızlarında ilerlemeleri için bir fırsat olduğunu ancak çocukların daha iyiyi görme şanslarının olmamasının negatif etki yaptığını belirtmişlerdir. Bu konudaki katılımcı görüşleri aşağıda verilmiştir.

Kızım şu an kendine yakın seviyedeki arkadaşlarıla bir arada. Bundan dolayı başarı bununla orantılı oluyor. Bir bakıma iyi oluyor. A şubesindeki çocuklar bir kerede anlarken kızım bazen 5 bazen 10 kerede anllyor. Haliyle ögretmenler bizim sınıfta daha ayrıntılı anlatıyorlar. Bu açıdan verimli bu uygulama. Ama bu durum kızımı hiç motive etmiyor...karma sınıfta olsaydı daha başarılıyı gözlemleyebilirdi belki daha iyi olurdu (Belma).

Bu uygulamanın etkin olduğunu düşünüyorum. Alan çocuklara daha fazla verebiliyorlar. Seviyeleri de birbirine yakın olduğu için çok zorluk çekmiyorlar (Serdar).

Aynı seviyede çocukların bir arada olması mantıklı. Kolay motive olabiliyorlar. Mesela soru çözüm süreleri birbirine yakın. Belki diğer sınıfta üç kere anlatılıyor (Selçuk).

Bu uygulama aslında çocuklara baskı yapıyor. Çocuğumda ya yapamazsam diye kaygı oluşuyor bu da bizim kötü sonuçlar almamıza neden oluyor... Başarısını 
olumsuz etkiliyor. Mesela A sınıfindaki çocuğu bilse birbirlerini örnek alırlar. Gel şu soruyu beraber çözelim, şuna da çalışalım filan diye. Seviyeleri düşük olana çocuklar birbirlerine ne verebilecek ki. Sinıf curcuna, kaos (Sevil).

Veliler açısından düzey derslikleri uygulaması akademik başarı ya da ilerleme için bir artı olarak görülmektedir. Uygulamanın eksi yönü ise çocukların psikolojisini olumsuz yönde etkilemesidir. Özellikle stres ve kaygı oluşturduğu için psikolojik olarak olumsuz etkilemektedir. Ayrıca çocukları alt düzeyde olan veliler çocuklarda daha iyisini yapamayacaklarına dair motivasyon eksikliği yaşadıklarını bu durumun da dolaylı olarak başarıyı düşürdüğünü ifade etmişlerdir. Velilerin bu konudaki düşünceleri aşağıda verilmiştir.

...Düzey dersliğinin şöyle bir dezavantajı var. En kötüleri bir sinıfa topladığınızda biz zaten yapamıyoruz diye kendilerini psikolojik olarak yıpratıyorlar. Endişe ve kaygl yaratıyor (Özlem).

... Ama sınav zamanlarında stresli oluyor. Yapamazsam diye endişeleri, korkuları oluyor (Selçuk).

Bu uygulama aslında çocuklara baskı yapıyor. Çocuğumda ya yapamazsam diye kaygı oluşuyor bu da bizim kötü sonuçlar almamıza neden oluyor... Başarısını olumsuz etkiliyor... Seviyeleri düşük olana çocuklar birbirlerine ne verebilecek ki (Sevil).

Çocukta stres var. Üzülüyor. Niye yapamadığını sorguluyor. Yeterli çalışmadığını söylüyoruz. Ama O öyle düşünmüyor. Ne kadar çalışırsam çalışayım ben A 'lar gibi yapamıyorum diyor. Karşılaştırma yapıyor. Ve kendine güveni azaliyor. Yapabildiklerini bile yapamam dediği oluyor mesela (Musa).

Veliler, alt ve üst sınıflar arasında arkadaşlık ilişkilerinde zaman zaman problem yaşandığını belirtmişlerdir. Özellikle alt sınıfta çocukları olan veliler üst sınıflardaki çocukların diğer çocuklara “eziksiniz” gibi ifadeler kullandıklarını bu nedenle de aralarında sürtüşmelerin olduğunu belirtmişlerdir. Aşağıda velilerin görüşlerinden örnekler verilmiştir:

Sinıf curcuna, kaos. Örnek davranış yok önünde... Sinıflar arasında olumsuz şeyler de söylenebiliyormuş. İşte üst sınıflar bizim çocuklara “ezikler” filan diyormuş. Geri zekalı konuma sokuyorlar. Çocuklar şeydir, acımasızdır biliyorsunuz (Sevil).

Okulda bir etiketleme oluyor. Mesela son şubede oldukları için ezik diyorlar. Bundan etkileniyor, ister istemez...Onu üzüyor (Belma), . 
Üst sınıfta çocukları olan veliler ise çocuklarının samimi dostluklar kuramadıklarını başarı odaklı arkadaşlık ilişkilerinin olduğunu vurgulamışlardır. Örneğin katılımcılardan Derya, bu durumu şöyle açıklamıştır:

Benim kızım hırslı bir çocuk. Sinıfin geneli de öyle. Özlem bu hafta matematikten 200 soru çözmüş ben de çözmeliyim diye hırslanıyor. Arkadaşlarılla sadece sınıf arkadaşı. Birlikte olalım, konuşalım yok. Yani karma olsaydı alt-üst derdi olmasaydı belki sadece iyi vakit geçirmeyi düşünürlerdi (Derya).

\section{Uygulamaya İlişkin Velilerin Düşünceleri: Pozitif Düşünce, Negatif Düşünce}

Düzey derslikleri uygulaması öğrenciler kadar velileri de etkilemektedir. Velileri, çocuklarının alt ya da üst sınıfta olması onları psikolojik olarak etkilemektedir. Uygulamaya ilişskin velilerin düşünceleri ana teması pozitif ve negatif düşünce olmak üzere iki alt tema olarak oluşturulmuştur (Şekil, 4).

Uygulamaya İlişkin Velilerin Düşünceleri

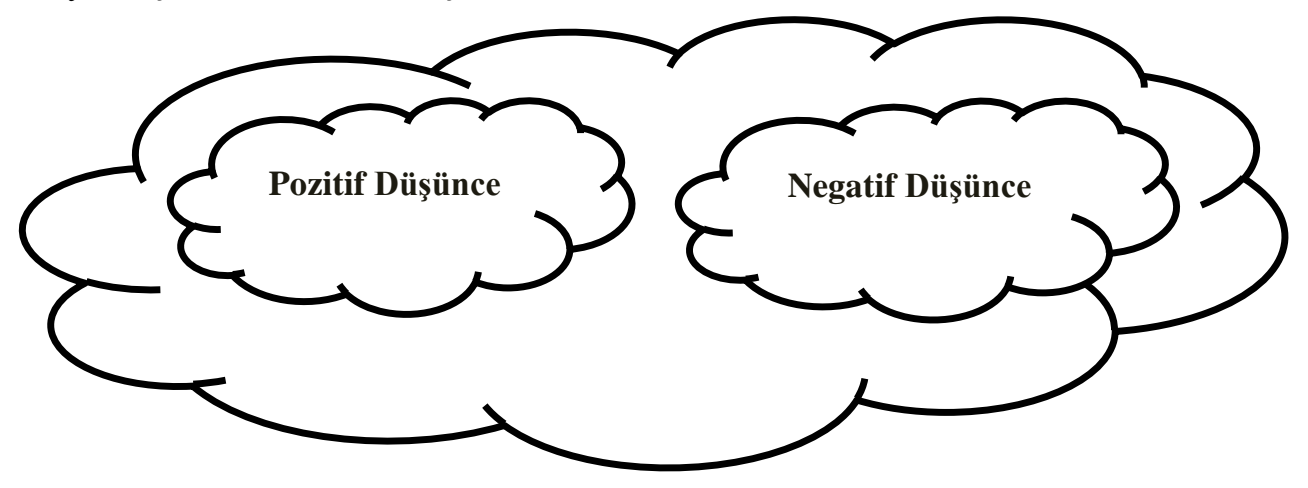

Şekil 4: Uygulamaya İlişkin Velilerin Düşünceleri Teması ve Alt temalar

Düzey derslikleri uygulaması öğrencilerin akademik başarılarına göre gruplandırmadır. Çocuklarının başarılı ya da başarısız olarak gruplandırılması ise velilerin duygularını etkilemektedir. Çocukları üst sınıfta olan veliler gurur duyup mutlu olmaktadırlar. Alt sınıfta olsalar üzüntü duyacaklarını belirtmişlerdir. Çocukları alt sınıfta olup ya da alt sınıfta olduğunda üzüntü ve endişe duyacak velilerin düşünceleri negatif düşünce teması içinde yer almıştır. Bu konudaki velilerin söylemleri aşağıdadır:

Biz velilerde hırs daha fazla...Her anne gibi başarılı çocuk istiyorum...D şubesinde olması beni psikolojik olarak çok yoruyor. Beni çok etkiliyor (Bu söylemde katılmcının gözleri doluyor). Ister istemez üzülüyor insan. Geleceği için kaygılanıyorum (Sevil). 
Çocuğumun A'da olması gurur verici. Mutlu oluyoruz onun başarısından. Düşük seviyede olsa üzülürdük...(Derya)

Çocuğun kaygısını, stresini biz de yaşıyoruz. Bizde çok büyük sıkıntı oluyor. Onu rahatlatmaya çalışsak da biz de içten içe endişeleniyoruz (Musa).

Çocukları alt sınıfta olsa da olumlu duygulara sahip olacaklarını önemli olanın çocuklarının mutluluğu olduğunu vurgulayan veliler de vardır. Çocukları alt sınıflarda olan velilerden bazıları üzüntü, stres, kaygı, endişe duyarken bazı veliler ise umut ve güven duygusu taşımaktadırlar. Bu düşüncedeki veliler için önemli olan çocuklarının ne hissettiğidir. Çocukları alt sınıfta olmasına rağmen olumsuz duygulara yer vermeyen veliler ile çocukları üst sınıfta olup ama çocukları hangi sınıfta olursa olsun mutlu ve gurur duyan veliler pozitif düşünce teması içerisinde yer almışlardır. Söylemleri aşağıda verilmiştir:

Ben çocuklarımda sadece akademik başarıyla hayata yaklaşmıyorum onların farklı alanlarda da başarılı olabileceğini düşünüyorum. Benim çocuğum benim gölgem değil ki benim başarımı gösterecek bir varlık değil...Her koşulda benim çocuğum benim için değerli ve özeldir, biriciktir (Özlem).

Bu durum beni olumsuz yönde etkilemiyor. Başarılı olsun isterim tabi ama mutlu olmasını daha çok isterim. Başarısızlı̆̆ benim çocuğumu mutsuz etmiyor...Yeter ki kendine olan inancl, güveni kaybolmasın. Ben stres yaparsam üzülürsem çocuk daha çok etkilenecektir. Güveni azalacaktır... Çocuk mutluysa ben de mutluyumdur (Selçuk).

Çocuğum A'da gurur duyuyorum ama ben B'de ya da C'de de olsa gurur duyardım. Onu yapabildikleri ölçüsünde değerlendirirdim. Her durumda çocuklarımla mutlu ve gururluyum. Bir sağlık problemi olsa ne yapardık (Serdar).

Düzey derslikleri uygulamasının kendilerini olumsuz yönde etkilemediğini vurgulamışlardır. $\mathrm{Bu}$ veliler, her durumda pozitif düşünceye sahip, yaşanılan durumların olumlu taraflarını görmeyi tercih etmektedirler. Ebeveyn olarak görevlerinin rehberlik etmek, güvenlerinin zedelenmesini önlemek olduğunu vurgulamışlardır.

\section{Sonuç ve Tartışma}

Araştırmaya katılan veliler açısından düzey derslikleri uygulamasına ilişkin görüşler; "Düzey Dersliklerinin Anlamı”, “Düzey Dersliği Oluşturma Ölçütleri”, “Düzey Derslikleri Uygulamasının Olumlu ve Olumsuz Yönleri” ve "Uygulamaya İlişkin Velilerin Düşünceleri” 
olmak üzere dört ana temadan oluşmaktadır. Düzey dersliklerinin anlamı temasında veliler düzey dersliklerini akademik olarak yakın başarı gösteren öğrencilerin bir arada olduğu gruplandırma şekli olarak tanımlamaktadırlar. Düzey derslikleri literatürde farklı şekillerde tanımlanmakla birlikte genel olarak düzey derslikleri uygulaması öğrencilerin bilişsel düzeylerini dikkate alarak benzer öğrenme hızına sahip öğrencileri aynı sınıf ortamında öğretim işlemlerini gerçekleştirilmesi olarak tanımlayabiliriz. Slavin (1993), Gömleksiz (1997), Cheung ve Rudowicz (2003) çalışmalarında düzey dersliklerini öğrencilerin kendi düzeylerine uygun dersliklerde öğrenim görmeleri olarak tanımlamışlardır.

Düzey dersliği oluşturma ölçütleri temasında ise veliler öğrencilerin akademik başarılarının yanında öğrenci hal ve tutumlarının, öğretmen kanaatlerinin, sanatsal ve sportif faaliyetlerdeki başarıların da dikkate alınması gerektiğgini vurgulamışlardır. Görüşme yapılan velilerden bir tanesi mevcut okulların ortamlarının yetersizliğinden dolayı sadece akademik başarılarının dikkate alınmasının doğru olduğunu düşünmektedir. Düzey derslikleri oluşturmada öğrencilerin akademik başarıları dikkate alınmaktadır. Öğrencilerin seviyeleri, okullarda yapılan genel sınav sonuçlarına ya da bir önceki yıldaki akademik başarı ortalamasına göre belirlenmektedir. Veliler ise bu uygulamanın yetersiz olduğunu, farklı ölçütlerin de getirilmesi gerektiğini vurgulamışlardır. Oakes (1995), Slavin (1993), Kulik (1992), Yılmaz vd. (2009) çalışmalarında bu çalışmanın bulgusuna benzer olarak düzey dersliklerinde ölçüt olarak öğrencilerin yılsonu ortalamaları, zekâ bölüm puanları, yetenekleri, hazır bulunuşluk düzeyleri, davranış notları ve öğretmenlerin öğrencileri hakkındaki görüşleri kullanılması gerektiğini belirtmişlerdir.

Düzey derslikleri uygulamasının olumlu ve olumsuz yönleri temasında ise veliler uygulamanın çocuklarının kendi bilişsel hızlarında öğrenmeleri açısından etkin olduğunu ancak sınıflar arasında arkadaşlık ilişkilerinin zedelenmesi ve çocuklarda endişe, kaygı, stres oluşturması gibi olumsuz yanlarının olduğunu vurgulamışlardır. Veliler çocuklarının kendi öğrenme hızlarında ilerlemesine olanak tanıdığı için uygulamanın etkin olduğunu ancak çocukların kendi seviyelerinin üstünü görmedikleri için de motivasyon eksikliği oluştuğunu belirtmişlerdir. Aslan, Küçüker, Gürbüzler (2014) düzey derslikleri ile ilgili tartışmaları üç grupta toplamışlardır. Bir grup araştırmacı (Slavin (1993), Braddock ve McPartland (1990)), düzey dersliklerinin öğrenciler üzerinde yararlı olduğunu çünkü üst seviyedeki öğrenciler daha hızlı ilerlerken alt seviyedeki öğrencilere ek örneklerle daha fazla yardım edilebileceğini vurgulamışlardır. Bir grup araştırmacı (Yılmaz vd. (2009); Saleh, Lazonder \& Jong, (2005); 
Gömleksiz (1997)) düzey derslikleri uygulamasının başarıya hiçbir etkisi olmadığı, bir grup araştırmacı (Boaler, William ve Brown, 2007; Aldan Karademir, 2007; Gömleksiz, 1997; Kulik ve Kulik, 1992) ise uygulamanın farklı açılardan (motivasyon, psikolojik sıkıntılar, yetersizlik duygusu vb.) sakıncaları olduğu üzerinde durmuşlardır.

Düzey derslikleri uygulamasının çocukların sınıflar arasında birliktelik oluşturmasına engel olduğu görülmektedir. Başaran (1974) ve Yılmaz vd. (2009)'ın çalışmalarında da belirttikleri gibi ilköğretim dönemi çocukları oyun gruplarına katılma çağıdır. 11-14 yaş dönemi çocukların ailelerinden çok akran grupları ile birlikte olma ve oyun aracılığıyla sosyalleşme ihtiyaçları oldukları bir dönemdir. Ancak düzey derslikleri uygulaması ile çocukların oyunla sosyalleşmelerinin, paylaşımlarının yerini akademik kaygı ile bütünleşen arkadaşlık ilişkileri almaktadır. Samimi dostluklar kurabileceği arkadaşı, kendinden daha üst ya da alt sınıfta olduğu takdirde diğer çocukların “ezik, kafasız, inek” gibi etiketlemelerinden etkilenerek arkadaşından uzaklaşabilmektedir.

Araştırmada veliler, uygulama nedeniyle çocuklarının psikolojilerinin olumsuz etkilendiğini de vurgulamışlardır. Alt sınıfta olmanın ya da üst sınıfta olup alt sınıfa geçme ihtimalinin olması çocuklarının aşırı kaygılı ve stresli olmasına neden olmaktadır. Kaygı, bireyi yaşamda etkileyen, tedirgin eden bir duygu olup bireyin davranışlarını olumsuz etkileyerek okul ortamlarında sık sık kendini gösterir. Bireyde güvensizlik, gelecekle ilgili kararsızlık, umutsuzluk yaşamasına neden olur (Hill \& Sarason, 1966). Düzey derslikleri uygulaması ile çocukta yoğun kaygı oluşması kendine olan güveninin azalmasına neden olabilir. Düzey dersliklerinin uygulama amacı akademik başarıyı artırmaktır ancak kaygıyı tetiklemesi nedeniyle akademik başarısını da tahmin edilenin aksine olumsuz etkileyebilir. Literatürde kaygı ve okul başarısı arasındaki olumsuz ilişkiyi ortaya koyan çok fazla çalışma vardır (Aysan, Thomsan ve Hamarat, (2001); Baltaş (2002); Erkan (1996); Man, Hall ve Stout (1981). Araştırma bulgularına göre velilerin ifadesiyle çocuklar akademik başarı sağlama açısından kaygı ve endişe içerisindelerdir. Erkan (1991)'nın yaptığı çalışmaya göre çocuk yoğun kayg1 yaşarsa ak1l yürütme ve soyut düşünme yönündeki zihinsel faaliyeti bozulur ve buna bağl1 olarak akademik başarısı da olumsuz etkilenir. Buna göre; düzey derslikleri uygulaması çocuğun kaygı seviyesini yükselterek akademik olarak başarı göstermesine de engel olabilir.

Düzey derslikleri uygulaması, sadece uygulama içerisinde olan çocukları değil velileri de etkilemektedir. $\mathrm{Bu}$ çalışmanın amacı düzey derslikleri uygulamasına velilerin gözüyle bakabilmektir. Bu nedenle araştırmada velilere bu uygulamanın onlara ne hissettirdiği sorusu 
yöneltilmiş ve pozitif, negatif düşünce olmak üzere iki alt tema oluşturulmuştur. Çocuklarının alt sınıfta olmasından ya da alt sınıfa geçme ihtimalinin olmasından dolayı en az çocukları kadar stresli, kaygılı veliler olmakla birlikte çocuklarının alt ya da üst sınıfta olmasından etkilenmeyen duruma daha olumlu, pozitif bakan veliler de vardır. Bu durumu; Erez, Johnson \& Judge (1995); bir durumu bazı kişiler olumlu bir şekilde yorumlarken, başka bir kişi aynı durumu olumsuz bir şekilde ele alabilir ifadesiyle açıklar. Olayı ya da durumu olumlu yorumlama ise literatürde pozitif düşünme olarak geçmektedir. Bekhet \& Zauszniewski, (2013); Tod, Warnock, \& Allmark, (2011) pozitif düşünmeyi, bireylerin karşı karşıya kaldığı olayların ve durumların, bütün yönleri ile kabul etmesinin ardından pozitif bir şekilde odaklanması ve yorumlamasıdır şeklinde tanımlamışlardır. Pozitif düşünme becerilerini etkin bir biçimde kullanan bireyler, içinde bulundukları koşullarla iyimser bir şekilde yüzleşerek stresli bir durumla karşılaştıklarında bu durumu kontrol edilebilir olarak değerlendirirler ve etkili baş etme stratejileri kullanırlar (Carver \& Scheier, 1998; Cantor, Langston, Zirkel, Fleeson, \& Flannagan 1999). Bu çalışmada da bazı velilerin çocuklarının başarılı ya da başarısız olma durumlarının kabul edebilmeleri, her koşulda benim çocuğum anlayışını benimsemeleri ve stresli ya da kaygılı olmadıklarını belirtmeleri nedeniyle pozitif düşünceye sahip olduklarını söylenilebilir. Naseem \& Khalid (2010)'e göre olumlu düşünme becerilerini etkin bir şekilde kullanabilmek, bireyin stres yaratan olaylarla daha iyi başa çıkmasına yardımcı olur. Ançak bir grup veli ise çocuklarının alt ya da üst sınıfta olmasından olumsuz yönde etkilenmektedir. En az çocukları kadar kaygı ve stres içerisindedirler. Psikoloji bilimine göre bu grup veliler negatif düşünce içerisindedirler. Olaylara olumlu yönden bakamayarak hep olumsuzluklarıyla değerlendirirler (Tod, Warnock, \& Allmark, 2011). Bu çalışmada da bir grup velide bu durum görülmektedir.

\section{Öneriler}

Okullarda düzey derslikleri oluşturulurken sadece genel sınav sonuçlarına göre değil öğrencilerin farklı yetenek ve becerileri, öğretmen kanaatleri gibi ölçütler de dikkate alınabilir.

Düzey derslikleri uygulaması yapılan okullarda öğrenci ve velilerin kaygılarını azaltabilmek amacıyla etkin rehberlik çalışmaları yapılabilir.

Sınıflar arasındaki ilişkilerin başarıya odaklanılmaması açısından bütün sınıfların katılabileceği sanatsal ve sportif faaliyetler düzenlenebilir.

Düzey derslikleri uygulamasının başarıya etkilerini görebilmek açısından deneysel çalışmalar yapılabilir. Öğrenci ve öğretmen görüşleri de alınabilir. 


\section{Makalenin Bilimdeki Konumu (Yeri)}

Eğitim Bilimleri Bölümü / Eğitim Programları ve Öğretim ABD

\section{Makalenin Bilimdeki Özgünlüğü}

Alanyazında özellikle ortaöğretimde yaygın bir kullanım olan düzey derslikleri uygulamasının öğrenci üzerindeki olumlu-olumsuz etkileri tartışılmaktadır.

Türkiyedeki çoğu okullarda uygulanan düzey derslikleri uygulamasının veliler tarafindan nasıl anlamlandırıldığını tespit etmek açısından araştırmanın önemli olduğu düşünülmektedir. Alanyazında düzey derslikleri uygulamasının veli görüşleri açısından ele alınan güncel bir çalışmaya rastlanmamıştır. $\mathrm{Bu}$ nedenle bu çalışmanın özgün bir değer taşıdı̆̆ düşünülmektedir.

\section{Kaynaklar}

Aslan G., Küçüker E. ve Gürbüzler A.(2014). Seviye sınıfları uygulamasına ilişkin öğretmen görüşlerinin değerlendirilmesi. International Journal of Human Sciences 11(2).

Ansalone, G. ve Biafora, F. (2004). Elementary School Teachers’ Perceptions And Attitudes To The Educational Structure Of Tracking. American Journal of Education. Academic Research Library. 125 (2), 249.

Aysan, F., Thomson, D. and Hamarat, E. (2001). Test anxiety, coping strategies and perceived health in a group of high school students: a Turkish sample. The Journal of Genetic Psychology; Child Behavior and Comparative Psychology, 162, 402-411.

Baltaş, A. (2002). Öğrenmede ve Sinavlarda Üstün Başarı. Remzi Kitabevi Yayınları, İstanbul.

Bekhet, A. K., Zauszniewski, A. (2013). Measuring use of positive thinking skills: Psychometric testing of a new scale. Western Journal of Nursing Research, 35(8) 1074-1093.

Boaler, J.; Wiliam, D and Brown, M. (2000). Students’ Experiences of Ability GroupingDisaffection, Polarization and the Construction of Failure. British Educational Research Journal. 26 (5). 631-648.

Braddock, J. H. and McPartland J. M. Alternatives to Tracking Educational Leadership 47(7): 76$79,1990$. 
YYÜ Eğitim Fakültesi Dergisi (YYU Journal of Education Faculty), 2019; 16(1):27-48, http://efdergi.yyu.edu.tr

Cady, J. L. (2011). The effects of implementing heterogeneous writing groups in a fifth grade classroom(Doktaratezi,RomaÜniversitesi). http://rdw.rowan.edu/cgi/viewcontent.cgi?article= 1264\&context=etd. 28.09.2018

Cantor, N., Norem, J., Langston, C., Zirkel, S., Fleeson, W. and Cook Flannagan, C. (1991). Life tasks and daily life experience. Journal of Personality, 59, 425-451.

Carver, C. S. and Scheier, M. F. (1998). On the self regulation of behavior. New York: Cambridge University Press.

Cheung C. K.; Rudowicz, E. (2003). Academic Outcomes of Ability Grouping Junior High School Students in Hong Kong. The Journal of Educational Research. 96 (4), $241-254$.

Christensen, L. B., Johnson, R. B. ve Turner, L. A. (2015). Araştırma Yöntemleri: Desen ve Analiz, (Çev. A. Alpay), Anı Yayıncılık, Ankara.

Creswell, J. W. (2013). Araştırma Deseni, (Çev. S.B. Demir), Eğiten Kitap. Ankara.

Erez, A., Johnson, D. E. And Judge, T.A. (1995) Self-deception as a mediator of the relationship between dispositions and subjective well-being. Personality and Individual Differences, 5, 597-612.

Erkan, Z. (1996). Grup rehberliğinin yüksek sınav kaygısı üzerindeki etkisine yönelik deneysel bir çalışma. III. Ulusal Psikolojik Danışma ve Rehberlik Kongresi, Çukurova Üniversitesi, Adana. Gömleksiz, M. (1997). Düzey Kümeleri: Temelegitim_kinci Asama Ögrencileri Üzerinde Bir Arastırma. Adana: Baki Kitap ve Yayınevi, No.11.

Halis, İ. (2002). Demokratik Sınıf Ortamı İçin Profesyonel Sınıf Yönetimi. (2.Baskı). Konya: Mikro Yayınlar1.

Heck, R.H., Price, C.L. ve Scott, T.L. (2004). Tracks As Emergent Structures: A Network Analysis of Student Differentiation. American Journal of Education. Academic Research Library 110(4), 321.

Hill, K. T. \& Sarason, S. B. (1966). The relation of test anxiety and defensivenes to intelligences, and school performance, over elemantary school years. A Futjer Longitudional Study. Monographs of The Society for Research in Child Development. 3, 92-104.

Karademir, Ç. A. (2007). Düzey Dersliklerinin İlköğretim 6. Sinıf Öğrencilerinin Fen Bilgisi Dersine İlişkin Akademik Başarıları ve Benlik Saygısı Üzerine Etkisi. Adnan Menderes Üniversitesi Sosyal Bilimler Enstitüsü, Yayınlanmamış Doktora Tezi.

Kulik, J.A. ve Kulik, C.L.C. (1992). Meta-Analytic Findings On Grouping Programs. Gifted Child Ouarterly. 36(2), 73-77. 
Kutnick, P., Blatchford, P., Clark, H., Macintyre, H. and Baines, E. (2005). Teachers’ Understandings Of The Relationship Between Within-Class (Pupil) Grouping And Learning In Secondary Schools. Educational Research, 47 (1), 1 - 24.

Man, A. F., Hall, V. and Stout, D. (1991). Neurotic nucleus and test anxety. The Journal of Psychology, 125, 166-173.

MEB, 1739 sayılı temel eğitim kanunu (http://mevzuat.meb.gov.tr/html/temkanun) Erişim tarihi: 12.04.2018, 17:46.

Merriam, S. B. (2013). Nitel araştırma. Desen ve Uygulama İçin Bir Rehber. (Çev. S. Turan), Nobel Akademik Yayıncılık, Ankara.

Miles, M.B., \& Huberman, A.M. (1994). Quality data analysis: An expanded sourcebook. Thousand Oaks: Sage Publications

Naseem, Z., and Khalid, R. (2010). Positive thinking and coping with stress and health outcomes: Literature review. Journal of Research \& Reflections in Education, 4, 4261.

Oakes, J. (1995). Two Cities” Tracking And Within School Segregation. Teachers College Record. 96(4), 681-690.

Slavin, R.E. (1993). Ability grouping in the Middle Grades: Achievement Effects and Alternatives The Elementary School Journal. 60(3), 471-499. 89(5), 535-552.

Saleh, M., Lazonder, A.W. ve Jong, T.D. (2005). Effects Of Within Class Ability Grouping On Social Interaction, Achievement And Motivation. Instructional Science, 33: 105-119.

Smith, J. A., Flowers, P., \& Larkin, M. (2009). Interpretative phenomenological analysis: Theory, method and research. Thousand Oaks, CA: Sage.

Tod, A., Warnock, C., \& Allmark, P. (2011). A critique of positive thinking for patients with cancer. Nursing Standard, 25, 43-47.

Yıldırım, A. ve Şimşek, H. (2013). Sosyal bilimlerde nitel araştırma yöntemleri. (6. baskı). Ankara: Seçkin Yayıncılık.

Yılmaz, S., Çengel, M., Vural, R., Gömleksiz, M. (2009). Düzey derslikleri: ilköğretim 7 - 8. Sınıf öğrencileri Üzerine bir durum Çalışması. Yüzüncü Y1l Üniversitesi, Eğitim Fakültesi Dergisi, Haziran, Cilt:6, Say1:1

Toomela, A., Kikas. E. ve Mottus, E. (2006). Ability Grouping In Schools: A Study Of Academic Achievement In Five Schools In Estonia. Trames, 10(60/55), 1, 32-43.

Zimmer, R. (2003). A New Twist In The Educational Tracking Debate. Economics of Education Review 22: 307-315. 


\section{Summary}

\section{Statement of Problem}

Students who complete secondary school education take the central exams organized by Ministry of National Education. These students enter high schools according to their achievement scores they get in the exams. In order to enable their students to enter more successful high schools, some secondary schools employ different implementations such as ability grouping between classes. The concept of ability grouping has been defined in different ways in literature (like the ability group, ability grouping, tracking, curriculum tracking). The purpose of classifying students according to their social or cognitive abilities may arise from the desire to educate them according to individual differences. However, as Halis (2002) stated measuring the ability is a challenge. There is the risk of misclassification in the case that there is no clear definition about which criteria to be used and by whom the ability will be measured. While secondary schools take this risk, in order to achieve a higher level of success they only focus on cognitive skills. Studies conducted in Turkey and other countries indicated that the implementation of ability grouping is generally evaluated through the views of teachers, administrators and students (Gömleksiz (1997), Yılmaz et al. (2009), Karademir (2007), Toomela et al. (2006), Zimmer (2003), Halis (2002)); however, parents' opinions were not included. In accordance with this situation, the aim of this study is to examine ability grouping from the eyes of parents. By enabling the parents to evaluate the implementation of ability grouping, their opinions about the effect of ability grouping on their children academically, socially and psychologically were aimed to be revealed.

\section{Method}

In this study, which aims to present the opinions of the parents who have children in the schools implementing ability grouping in secondary school level based on their experience, phenomenology design was used. In this study, maximum variation sampling technique, which is a method of purposeful sampling, was preferred. Within the scope of the study, the opinions of 10 parents, consisting of 3 males and 7 females, were included. The study was carried out with the parents of 6th and 7th graders in a school in Denizli province that implements ability grouping. The data was collected through interviews, and in the analysis of the data content analysis method was used.

\section{Findings}


According to the views of the parents participating in the study, the opinions on ability grouping were grouped under four themes including "The Definition of Ability Grouping", "The Criteria to Design Ability Grouping", “The Positive and Negative Aspects of the Application of Ability Grouping" and " The Thoughts of Parents about the Implementation". Under the theme of The Definition of Ability Grouping the parents defined ability grouping as grouping the students who have similar academic success levels. As for the criteria to design ability grouping, the parents emphasized that along with students' academic success, students' behaviours and attitudes, teachers' opinions about students, students' success in art and sports activities need to be taken into account. One of the parents interviewed believes that because of the inadequacies in the conditions of current schools, only academic success should be considered. When it comes to the theme of pros and cons of ability grouping, the parents stated that the implementation is effective as it enables their children to learn according to their own cognitive pace; however, it creates some disadvantages for children in terms of peer relationships and leads to stress and anxiety. The implementation of ability grouping not only affects the feelings of children but also that of the parents. Whereas the parents whose children are in high level classes feel happy and proud, the parents having children in low level groups are unhappy and worried. Nevertheless, there are also some parents thinking positively who don't pay attention to whether their children are in low or high level class but give importance to their being happy and healthy.

\section{Discussion and Conclusion}

While designing ability grouping between classes, not only general exam results but also some criteria such as students' different skills and abilities and teachers' opinions about students can be taken into account .

Effective counselling activities can be conducted in order to reduce the concerns of students and parents in the schools where ability grouping between classes is practised.

Arts and sports activities that all classes can participate in can be organized so that the relationships between the classes are not based on the academic success.

Experimental studies can be done in order to find out the effect of ability grouping on success. Student and teacher views can also be taken. 